\title{
POLÍTICA DA CONSIDERAÇÃO: AÇÃO E INFLUÊNCIA NAS TERRAS BAIXAS DA AMÉRICA DO SUL
}

\author{
José Antonio Kelly ${ }^{1}$ \\ Marcos de Almeida Matos ${ }^{2}$
}

${ }^{1}$ Universidade Federal de Santa Catarina, Florianópolis, SC, Brasil

${ }^{2}$ Universidade Federal do Acre, Rio Branco, AC, Brasil

\section{Introdução}

Este artigo tem como objetivo sugerir elementos para pensar as formas de ação e organização dos coletivos indígenas nas terras baixas da América do Sul a partir da combinação de duas ideias acerca das relações entre as pessoas e das formas de agir socialmente significativas: a) toda ação significativa (i.e., que tem efeitos e consequências perceptíveis) poderia ser explicada - ou compreendida, ou justificada, ou questionada etc. - como envolvendo a separação entre uma pessoa que age e uma outra pessoa tomada como a causa da ação; b) ser reconhecido como pessoa, ou ocupar o lugar de um agente moral, implica estar sob a consideração de uma outra pessoa. Este último aspecto encontra uma boa tradução na expressão inglesa regard, que contextualmente denota "cuidado", "olhar", e "pensar em alguém" ou "em alguma coisa de uma maneira particular". Esta tríade de significados guiará a primeira parte do artigo, em que exploramos diferentes contextos etnográficos nos quais "ser objeto de consideração" evoca "estar sob o cuidado", "ser visível" ou "estar no pensamento de alguém". Aqui é preciso observar que ser um "objeto da consideração" não é o oposto a ser um "sujeito que considera", pois o objeto da consideração é sempre um outro sujeito. Nossas principais fontes de inspiração foram as evidências presentes em trabalhos etnográficos disponíveis sobre os coletivos indígenas amazônicos, bem como a "teoria da ação melanésia" elaborada por Marilyn Strathern em O Gênero da Dádiva (1988). 
A separação entre uma causa e um agente estrutura a ação como performance. Se a causa e o agente podem ser individuados, o efeito de sua interação é a sua relação (Strathern 1988:272). Mas esse efeito é sempre incerto. As pessoas podem compelir os outros a agirem moralmente (parafraseando Wagner 1981) e, a partir desta perspectiva, se o outro age da maneira desejada, então se tem uma medida da eficácia pessoal daquele que pretendeu ser a causa de sua ação. De outra perspectiva, um agente é aquele que age tendo um outro específico em mente (i.e., aquele que causa a sua ação). Ele foi ativa ou passivamente provocado a agir por este outro, e as expectativas de quem o compeliu à ação podem ou não ser satisfeitas. De qualquer forma, sempre existem alternativas de ação que excluiriam ou ignorariam aquele outro que pretendeu ser a causa. Todo ato implica, de uma forma ou de outra, uma seleção (Strathern 1988:277). Sempre cercada de incerteza em relação à eficácia e ao resultado da seleção que opera, a relação que se produz é atualizada ou transformada através da circulação de palavras, alimentos e coisas. Há então uma espécie de "política da consideração" envolvendo a interdependência de pessoas que alternam as respectivas posições enquanto "causa dos atos de outrem" e "agente que tem outrem em mente".

A segunda, a terceira e a quarta partes deste artigo exploram essas ideias de performance, eficácia e modalidades de causação. Algumas dessas ideias têm ainda implicações para a análise das formas da política nas "sociedades contra o Estado" (Clastres 2003), e também do operador cosmológico maestria-domínio descrito por Fausto (2008), o que será objeto das partes finais do artigo.

\section{Como chegamos aqui}

Durante as pesquisas de campo empreendidas por um dos autores deste artigo entre os Yanomami do Alto Orinoco, ao longo de um estudo acerca das relações entre médicos brancos e as pessoas yanomami, uma variedade de situações se apresentou como aspectos daquilo que coube referir como "um certo modo da ação indígena" (Kelly 2011). Quase invariavelmente, os pacientes yanomami relatavam sobre suas passagens pelo hospital na sede do município como se eles tivessem sido "mandados" pelos médicos, e nunca como se tivessem ido por vontade própria. De uma maneira parecida, as histórias de alguns yanomami sobre como eles terminaram reunidos na missão de Ocamo durante os anos 1970 contam como os parentes que já estavam na missão os fizeram ir viver com eles. 
Também o modo como os Yanomami se relacionavam com os brancos que foram trabalhar com eles indicava algo nesse sentido: os Yanomami insistiam em pedir aos brancos que com eles conviviam (aos médicos ou ao antropólogo, por exemplo) comida ou artefatos industrializados, apesar da resistência desses brancos em ceder suas coisas (eram sempre poucas coisas para muita gente). Mesmo assim, alguns yanomami sempre conseguiam o que queriam. Seu procedimento era sentido como um tipo de "extração" da comida ou das mercadorias doadas. Há alguns relatos sobre como um pretenso comerciante yanomami fora obrigado a fechar o seu incipiente comércio na aldeia por não ser capaz de resistir à extração de objetos levada a cabo por seus parentes. Também se pôde assistir nas reuniões os Yanomami apresentando-se como desamparados ou passando necessidade diante de brancos reputados como mais poderosos (políticos, militares ou representantes das mais variadas instituições) ou, ao contrário, como assertivos e ameaçadores: em ambas as situações, o objetivo era conseguir dos brancos (ou de suas instituições) os bens ou serviços reivindicados (em particular, aqueles que dizem respeito ao atendimento da saúde nas aldeias). Em todos esses casos eram notáveis as intenções de causar nos interlocutores efeitos que os compelissem a agir segundo as formas intencionadas pelos Yanomami, como se fosse sempre preciso agir sobre as condições da ação dos outros.

Por outro lado, existem também evidências linguísticas em sintonia com estes modos de agir ou de fazer agir. Os Yanomami podem se referir aos seus aliados como aqueles com os quais eles praya- ma-yo- $u$, sendo que o causativo -ma- e o recíproco -yo- apresentam-se em conjunto para significar "nós nos fazemos um ao outro dançar", isto é, são aliados que se convidam reciprocamente para os ciclos festivos das comunidades. Amigos ou aliados também podem ser referidos como aqueles com os quais rimi-ma-yo-u, "nós causamos boas relações de visitação e troca". De forma similar, pode-se dizer também nohimayou, que literalmente significa "nós causamos amizade uns nos outros", assim como os inimigos, napëmayou, "nós causamos inimizade uns nos outros". Este uso tão comum do causativo, e especialmente a sua ocorrência com um recíproco, é um índice do entendimento das formas de relação e ação.

A releitura de outros trabalhos, em especial o de Gow (1991) entre os Piro, de Surrallés (2009) entre os Candoshi, e o de Allard (2010) entre os Warao, bem como parte dos resultados da pesquisa de doutoramento de Matos, outro autor deste artigo, entre os Manxineru (Matos 2018a) nos convenceram de que esse "modo de ação" pode constituir um traço mais geral entre os povos da região. Enquanto tentávamos elaborar uma imagem conceitual desses modos de ação e de influência, empreendemos um 
diálogo com os trabalhos de Lima (2005), Bonilla (2005, 2016), Fausto (2008), Vanzolini $(2011,2015)$, Sztutman $(2012,2009)$ e Costa $(2013,2017)$, o que nos levou a considerar mais diretamente os temas do poder, da política e da maestria em relação à agência. Não poderíamos aqui pretender fazer uma revisão satisfatória da literatura etnográfica pertinente, mas esperamos que esses diálogos sejam suficientes para iluminar certas potencialidades de nossa abordagem no que diz respeito aos temas considerados.

\section{Consideração: cuidado, ou "pensando nos outros"}

\section{O marido e a esposa}

A análise de Gow sobre as relações conjugais entre os Piro do baixo Urubamba é, senão a primeira, uma das mais claras e finas descrições dessa relação em termos da consideração recíproca, ou de um "pensar no outro": os atos de um esposo ou de uma esposa são frequentemente descritos como dirigidos ao cônjuge, como se fossem executados porque o agente estava pensando em sua companheira ou companheiro (Gow 1991). Da mesma forma, entre os Manxineru do alto rio Iaco, é mais comum ouvir um homem dizer que vai pescar porque sua mulher quer comer peixe, ou ouvir de uma mulher que ela vai fazer caiçuma porque seu marido deseja beber, do que ouvir que alguém faz essas coisas por sua própria necessidade ou vontade.

Gow descreve a divisão sexual do trabalho como implicada simultaneamente na autonomia e na ajuda mútua que o casamento supõe (1991). A relação é constituída pela participação voluntária de cada um, e o homem ou a mulher podem deixar o seu cônjuge a qualquer momento. Espera-se de um homem que ele construa uma casa, limpe seu roçado e inicie o plantio de diversos cultivares. À mulher cabe cozinhar, zelar pelo roçado, e produzir caiçuma. Além disso, cabe ao homem prover carne de caça, peixe e mercadorias adquiridas junto aos patrões brancos que vivem longe das comunidades. A carne é dada pelo homem para a sua mulher, que a divide e a faz circular entre as suas parentas; e a caiçuma é produzida pela mulher e se faz circular pelos homens. Através do oferecimento de caiçuma, os homens convidam outros homens para trabalhar em seus empreendimentos, alternando-se nos papéis de anfitriões ou trabalhadores nos mutirões para a abertura de roçados ou a construção de casas, por exemplo.

Em certo sentido, pensar no cônjuge durante uma atividade é explicado como tomar o cônjuge como causa da ação: o marido caça para a sua esposa, a esposa faz caiçuma para o seu marido. O verdadeiro critério para atestar a 
eficácia dos atos de um marido enquanto marido são os atos recíprocos de sua esposa, e vice-versa. Gow descreve uma relação de demanda mútua, na qual a falha em atender às expectativas do cônjuge resulta em uma interrupção da reciprocidade entre o casal (a mulher pode parar de fazer caiçuma para o seu marido, ou se recusar a ter relações sexuais com ele etc.).

Observando tal reciprocidade, o antropólogo poderia descrever esse tipo de relação como uma espécie de troca. No entanto, quando um dos autores deste artigo tentou fazê-lo, seus interlocutores manxineru recusaram a comparação: mais do que algo que se faz com vistas ao que se obtém em troca, trata-se de agir pensando no outro, ou agir diante do cônjuge (cf. Matos 2018a:124-125).

\section{Parentes reais}

"A relação conjugal é a única relação que pode ser caracterizada como uma relação de demanda recíproca" (Gow 1991:128). ${ }^{1}$ Em contraste, aqueles que se consideram como "parentes reais" dizem se lembrar uns dos outros constantemente, por exemplo, ao partilhar a carne obtida em uma caçada bem-sucedida. Lembrar de um parente significa também antecipar suas necessidades, já que nas relações entre "parentes reais" as coisas não são pedidas explicitamente (Gow 1991:165). Sejam formuladas como demandas explícitas (como no caso das relações conjugais), sejam formuladas como expectativas antecipadas (como entre os parentes reais), as ideias de lembrar-se dos parentes ou do cônjuge ou de pensar neles refletem uma diferenciação entre o agente e a causa de sua ação: a pessoa que é lembrada ou considerada com carinho é tomada como a causa das ações, que são assim uma resposta ou uma antecipação diante dos outros.

O estudo de Surrallés (2009) sobre os afetos entre os Candoshi mostra como os sentimentos, as sensações e os pensamentos são concebidos como intrinsecamente conectados. Um de seus exemplos-chave é especialmente interessante: magish chinakish, que Surrallés traduz por "coração que pensa", ou "coração que ama". Em busca de uma tradução mais definida, ele hesita entre "coração que se lembra" ou "coração que domestica", afirmando assim que as ideias de amor, pensamento e domesticação estão imbricadas na linguagem e na prática candoshi, sendo expressão de um princípio relacional muito presente. Sobre a relação entre o amor e o pensamento (deixemos a ideia de domesticação para ser abordada abaixo), Surrallés diz que os Candoshi "pensam sobre tudo o que é necessário para cuidar, alimentar, proteger, ou simplesmente ajudar, aqueles que em um dado momento e por razões diversas dependem de quem pensa, como no caso da domesticação" 
(2009:116). Neste contexto, pensar "é sempre pensar em alguém (ou no interesse de alguém)" (:117). Alès (2000:135-136) diz que os Yanomami concebem suas ações cotidianas como formas de evitar o sofrimento próprio ou de seus parentes. Não deixar uma pessoa sofrer é uma formulação em negativo daquilo que os Candoshi descrevem como agir sob o interesse de alguém que depende daquele que age.

\section{Crianças}

Surrallés dá especial atenção às relações de dependência, o que nos leva às relações entre pais e filhos. Entre os Piro, segundo Gow, as crianças ocupam proeminentemente a posição de dependentes; seu estado de desamparo evoca os atos de cuidado de seus pais, que marcam nas crianças uma memória e são reciprocamente correspondidos por elas com um respeito carinhoso (1991:50). Surrallés descreve uma dinâmica similar de constituição dos afetos na criação das crianças candoshi (2009:71), como o faz Allard junto aos Warao (2010:95).

O termo yanomami moyawë significa costumeiramente estar alerta, ser prudente ou consciente do que está acontecendo ao redor. Usado em relação aos bebês ou às crianças pequenas, este termo se refere a um estágio de maturidade, quando a criança já aprendeu a responder apropriadamente às interpelações de seus parentes mais velhos, explicitando a conexão entre as respostas aos atos de cuidado e o entendimento das convenções sociais. Enquanto as crianças são totalmente dependentes, elas são incentivadas progressivamente a estabelecer o tipo de interdependência mútua que vigora entre adultos, sobre a qual repousa uma ideia de pessoa com forte conotação moral. Isto significa que a maturação é a passagem da dependência para a interdependência, e não à independência - como observou Strathern no contexto melanésio (1988:93).

Os casos mencionados nos convidam a ver no desamparo das crianças a causa dos atos de cuidado de seus pais (uma abordagem semelhante pode ser lida em Gow 2000). De maneira interessante, a etnografia de Costa $(2013,2017)$ sobre os Kanamari nos apresenta o aspecto inverso da relação (voltaremos a isto): o foco parece estar nos pais como causa dos laços de dependência, e o que se enfatiza é uma relação de alimentação que institui a necessidade de uma mãe ou pai que alimenta. Assim, a análise de Costa enfatiza menos a consolidação da interdependência em forma de memória e respeito, e mais uma outra face da moeda: o afrouxamento progressivo dos laços de dependência à medida que se estabelecem novos vínculos de dependência quando os filhos se tornam pais. 
Além disso, a concepção e o nascimento de uma criança a colocam como um terceiro termo, formatando dinamicamente a relação diádica entre marido e esposa: em certo sentido, um filho demanda de seus pais uma série de cuidados necessários à sua maturação (resguardos, dietas, banhos etc.), desta maneira, mesmo antes de seu nascimento, a criança atua como causa das ações que um marido empreende para a sua esposa, e vice-versa. E um mesmo sentido, a criança também atua sobre as relações entre genros e sogros, como entre pais (i.e., avós) e filhos. Trata-se da constituição de uma dinâmica ternária subjacente aos dualismos, assunto ao qual voltaremos adiante.

\section{Sob o olhar ou sob a consideração de outrem}

Voltemo-nos para o aspecto "olhar para alguém" contido na ideia de "considerar". Os temas da visibilidade ou da invisibilidade estão intimamente ligados ao xamanismo na região amazônica. Se ver o mundo espiritual é uma característica marcante do xamanismo, não podemos nos esquecer que esse "ver" é matéria de uma atenção ou de um cuidado recíproco que se estabelece entre xamãs e espíritos. No xamanismo yanomami, por exemplo, ser visto pelas imagens-espírito é uma precondição para a aquisição da habilidade de ver o mundo das imagens-espírito como esses espíritos o veem. A detalhada exposição de Davi Kopenawa sobre a iniciação xamânica yanomami enfatiza como o iniciando deve primeiramente se perceber em seus sonhos como objeto de interesse dos espíritos. Durante a iniciação, são os espíritos que primeiro o veem e que cantam, enquanto o iniciando é compelido pelos xamãs mais velhos que o guiam no processo a reconhecer os diferentes tipos de espírito e a responder a eles (Kopenawa \& Albert 2015). ${ }^{2}$

Em contextos mais corriqueiros, muitos etnógrafos perceberam como uma sofisticada política da visibilidade e do ocultamento governa o manejo de objetos e mercadorias na vida comunitária (ver Hugh-Jones 1992; Allard 2010; Ewart 2008; Matos 2018a). Em certo sentido, a visibilidade de um item corresponde à sua disponibilidade quase obrigatória, e é por isso que as pessoas tendem a manter itens de valor ou por vezes tipos de comida longe das vistas dos visitantes (daí a presença comum de malas ou baús dos mais variados tipos nos casarios das aldeias amazônicas). Os comentários de Ewart sobre a distribuição de coisas em uma casa panará são, com alguma variabilidade, pertinentes a outras sociedades amazônicas. 
Ao entrar em uma casa, não se percebe sinais visíveis de riqueza da habitação ou de seus moradores, sejam miçangas, roupas, ornamentos de pena, potes e panelas, equipamentos de caça ou de pesca, ou qualquer tipo de objeto valioso. Esses itens são cuidadosamente mantidos fora da vista das pessoas, e aparecem apenas durante alguma cerimônia ou quando são necessários (2008:516).

O que Allard observa sobre as razões deste tipo de prática também pode ser estendido para outros coletivos indígenas: "a exibição de coisas pode suscitar pedidos legítimos ou despertar inveja, [...] os primeiros são difíceis de recusar, e a última, sendo motivo de feitiçaria, pode ser letal. A discrição é sempre um requisito" (Allard 2010:36). Para falar de outra forma, ocultar as coisas é um modo eficaz de evitar o desejo que outras pessoas sentem por tais objetos. Nos termos da discussão que viemos fazendo, a discrição é exercida no sentido de evitar causar em outra pessoa o desejo ou interesse por alguma coisa. Esse "evitar causar o desejo em outrem" é análogo aos esforços das pessoas para não aparecerem ao olhar de espíritos malfazejos. Ambos os contextos envolvem os problemas que dizem respeito à assimilação da presença pela disponibilidade. Algo que é presente, mas não obstante indisponível, representa um problema: ou o desejo insatisfeito leva à inveja e às vezes provoca o feitiço, ou leva à doença e à morte, quando os espíritos carregam aquilo que estava indisponível mas não obstante presente.

Entre os Manxineru, por exemplo, é comum ver os pais de crianças pequenas admoestarem seus filhos para que eles não brinquem de atravessar nadando poços no rio: a passagem de uma criança pela cumeeira da casa dos espíritos aquáticos desperta o desejo destes por aquele potencial xerimbabo. Assim também crianças novas não devem ficar no chão do terreiro ou tomar banho na cacimba depois do crepúsculo, por motivos análogos. Em toda a Amazônia Ocidental é comum ouvir casos nos quais a recusa em dar uma filha em casamento aos poderosos xamãs de antigamente resultou no adoecimento da menina ou de seus pais.

\section{A causa ineficiente}

Se a "política da consideração" ou "do olhar" envolve se tornar ou evitar ser objeto da consideração alheia, deveríamos em seguida nos perguntar sobre as consequências de um aspecto inverso, isto é, de não ser capaz de se tornar objeto de consideração alheia, ou ainda de não conseguir causar a ação do outro. A falha em induzir o outro a agir é um sinal em geral preocupante da ineficácia pessoal. Nesse sentido, um certo tipo de ineficácia é sempre parte da frustrante experiência indígena com os "brancos", especialmente quando no ambiente desses brancos, como na cidade. Allard, por exemplo, observa que, 
de fato, o egoísmo e a ganância dos brancos e criollos, o fato de eles exporem objetos e mercadorias como se estivessem tentando maliciosamente suscitar a inveja, o fato de que eles expõem infinitos novos objetos mas ao mesmo tempo se recusam a dar esses objetos para os carentes Warao, isso revela a inabilidade de agir a partir da consideração pelos outros (2010:35).

A insensibilidade dos brancos diante dos modos indígenas de catalisar a ação alheia representa para estes últimos um verdadeiro mistério moral, que coloca em questão a humanidade dos primeiros. Isto traz à mente o modo como os Yanomami se espantavam com a presença de pessoas pobres, sem casa, revirando lixeiras em busca de comida em Puerto Ayacucho. Algo desse espanto é traduzido pelos comentários que Davi Kopenawa faz por ocasião de sua visita a Nova York.

No entanto, se no centro dessa cidade as casas são altas e belas, nas bordas, estão todas em ruínas. As pessoas que vivem nesses lugares afastados não têm comida e suas roupas são sujas e rasgadas. Quando andei entre eles, olharam para mim com olhos tristes. Isso me deu dó. [...] Os brancos que criaram as mercadorias pensam que são espertos e valentes. Mas eles são avarentos e não cuidam dos que entre eles não têm nada. [...] Rejeitam-nas e deixam que sofram sozinhas. Nem olham para elas e, de longe, apenas as chamam de pobres (Kopenawa \& Albert 2015:431).

Essa avaliação feita pelos Yanomami pode ser compreendida como a constatação da incapacidade dos brancos em compor relações de parentesco. Mas também permite sugerir que o espanto provém da separação entre o "olhar" o outro e o "cuidar" ou "se importar" com ele. O que causa espanto é como os brancos podem ver seus semelhantes sofrendo, olhar para eles e por eles serem vistos sem que isto os induza a qualquer tipo de cuidado ou de resposta. Que um cuidado não seja induzido por esse "ver o outro" é como desconectar os atos de suas causas presumidas. A ineficácia dos brancos em serem causas recíprocas de suas ações está implicada naquela incapacidade de compor relações de parentesco, e é isto também que lança dúvidas sobre o status moral ou humano dos brancos.

Tanto os bens visíveis não doados a outros quanto a falta de reação diante do óbvio sofrimento das pessoas denotam uma causa ineficaz. Quebrando a ligação entre a causa e o agente, uma ligação que é tão lógica quanto moral, essas situações revelam diferentes facetas de uma deterioração do parentesco, que em nosso contexto pode ser definido como "agir tendo em mente outras pessoas" (ou "agir causado por outras pessoas"). 
Quando um efeito que deveria atestar a capacidade de uma pessoa não se faz visível no ato daquele que supostamente foi provocado a agir, o que fica patente é a incerteza relativa à humanidade de quem procurava provocar um resultado. A falta de respostas dos brancos pode colocar em questão a sua humanidade, mas coloca implicitamente em questão também a humanidade dos indígenas, e talvez por isso seja comum ouvir os indígenas dizerem, em situações de marcado desequilíbrio ou desigualdade, que os brancos não os veem como seres humanos. O equilíbrio ou a alternância entre ser a causa da ação de outra pessoa e agir em resposta à outra pessoa é uma qualidade fundamental da personitude. Estar fora da consideração dos outros, não ser referência ou causa das ações alheias, equivale a perder a humanidade. Por isso também podemos ler em diversas etnografias que não é possível conceber um indivíduo isolado. Uma pessoa é sempre parte de um coletivo de pessoas - um casario, um grupo de parentes, uma comunidade. Entre os Manxineru que vivem no alto rio Iaco, por exemplo, "pessoa" se diz yine, um lexema inerentemente plural, para o qual não existe forma singular: tudo o que pode existir enquanto pessoa deve existir antes como um conjunto de pessoas. Lima, ao analisar a composição de um grupo social, nos informa que "a experiência yudjá pareceria dizer aos homens que a menor unidade obtenível é um homem e sua família, basicamente o par conjugal" (2005:90).

Talvez sejam as crianças órfãs, que não foram objeto do cuidado de parentes mais velhos, aqueles que sofrem mais com as consequências de serem uma causa ineficaz, ao não estarem sob o olhar ou a consideração de alguém. Em situação análoga estão os animais domésticos ou de criação que não possuem um dono definido, como aqueles descritos pelos Kanamari como "da comunidade" (Costa 2013:480), e também os objetos por vezes doados pelas agências indigenistas, igualmente "para as comunidades", e que vão se deteriorando no abandono. Em certo sentido, o jovem solteiro deseja ansiosamente se casar pela razão oposta: ele é dependente de outras pessoas, e precisa, para se engajar numa relação de interdependência, agir para contrabalancear seu estatuto como causa. Ou, segundo os termos sugeridos por Costa (2013), ele precisa agir para sair contextualmente de uma relação de alimentação e adentrar em relações de comensalidade. 


\section{Causa, agente e performance}

Nossa apresentação não estaria completa se não enfatizássemos o caráter performativo da articulação entre a causa e o agente. É preciso observar que a circulação de palavras, comidas e coisas compõe ou constitui as relações: ela não é apenas índice dessas relações, não apenas as significam ou exemplificam. Este é apenas outro modo de dizer que os efeitos das ações que visam compelir alguém são sempre incertos: a relação é constantemente transformada ou atualizada, seja no sentido desejado, seja no indesejado.

Tomemos como um primeiro exemplo as relações entre maridos e esposas, tais como pensadas pelos Piro. Podemos dizer que os produtos do trabalho ou da "procura" de cada um são índices da qualidade da relação, mas isto implicaria que a relação, ela mesma, fosse feita de alguma outra coisa (como a fumaça que é feita pelo fogo), o que seria enganador. É melhor imaginar que esses produtos, originados ao longo do processo de elicitação mútua dos atos dirigidos reciprocamente aos cônjuges, são a relação. A descrição que Gow fez da destruição da casa e dos pertences de um adulto falecido, com o objetivo de evitar que a alma do morto fique saudosa de seus parentes vivos, é instrutiva: "a alma do morto não está presa ao seu cônjuge vivo, mas à sua relação marital com aquele cônjuge: a alma do morto está presa à relação material em si, e não ao seu cônjuge enquanto pessoa" (1991:185). Os lamentos funerários entre os Yanomami e os Candoshi (ver Surrallés 2009) levam-nos a pensar que o que se perde nos dois casos é a relação e o seu contexto (a comida preparada pelo/a falecido/a, o roçado feito conjuntamente...), e é isto o que dá forma à perda.

Entre os Manxineru do alto rio Iaco, o uso inter-relacionado de nomes, apelidos, vocativos de parentesco e relações jocosas ou de respeito compõe relações, transformando contextos ao passo que, simultaneamente, se constituem conforme esses contextos. Nomes, termos de parentesco e modos de brincar ou de se respeitar não são regras a serem seguidas, mas antes "bases para a improvisação", como Wagner diria (1972). Há uma proliferação de nomes ou apelidos pessoais que emergem em cada esfera significativa de interação: desde um primeiro nome, dado pelos genitores ou pelos avós, que atua na individualização e na composição da pessoa, passando por um nome carinhoso pelo qual a pessoa é referida ou chamada por seus irmãos mais velhos, pelos apelidos jocosos usados por cunhados e primos até um nome oriundo da língua portuguesa, muitas vezes tomado das famílias dos antigos patrões ou companheiros de seringal, nome que é mais usado na escola ou na interação com os órgãos indigenistas. Aqueles apelidos ou nomes proliferam e são usados por pessoas específicas para dar a cada relação - seja ela 
entre primos, cunhados ou parentes distantes etc. - um caráter específico. Nomes e termos vocativos são usados para provocar respostas naqueles que são assim endereçados. De qualquer forma, o ato de chamar uma pessoa por um apelido ou por um termo de parentesco guarda a expectativa de dispor essa pessoa a adotar respostas específicas, e assim compõe a relação ela mesma (cf. Matos 2018b).

Um uso semelhante de termos vocativos, para elicitar ou transformar relações, pode ser observado entre os Yanomami, efeito que se vê amplificado durante os seus diálogos cerimoniais. Estes diálogos são meios para resolver tensões entre comunidades, e, dada essa enorme relevância política, há um aumento da capacidade transformadora do uso dos termos de parentesco. Por exemplo, se os anfitriões e visitantes têm a intenção de reduzir suas diferenças, os termos de afinidade direta que normalmente seriam empregados entre parentes distantes são substituídos por aqueles que evocam o convívio entre corresidentes. O diálogo cerimonial incorpora o significado e a função de diferentes vocalizações e mudanças de gênero usadas nas circunstâncias cotidianas, tanto para tornar visíveis as relações entre visitantes e anfitriões quanto para estimular a sua transformação (Kelly 2017). Naturalmente, o resultado do diálogo e, portanto, a eficácia das substituições dos termos de parentesco são sempre incertos. ${ }^{3}$

Voltando aos Manxineru, as relações jocosas - principalmente entre afins de mesma geração - e as relações de respeito - principalmente com parentes mais velhos que vivem juntos ou com os sogros - também criam seus próprios contextos de interação: as pessoas dizem que são primos porque brincam uns com os outros, embora sejam as relações jocosas em si que os tornam primos. De Vienne (2012:172) faz uma observação similar sobre as relações de brincadeira entre os Trumai do Xingu, acrescentando que parte do contexto jocoso envolve um grau de incerteza em relação ao seu próprio frame, no sentido de Bateson (De Vienne 2012:165). A recursividade entre a relação e a jocosidade (que é a causa e qual o efeito?) ilustra como a relação jocosa não "descreve" ou "significa" a relação, mas é a própria relação, ou a compõe. Perguntas sobre o frame da brincadeira iluminam a incerteza do resultado. São estas as qualidades que a nossa conceituação da "performance" espera transmitir.

Há ainda uma correlação muito presente quanto aos tipos de relação entre os parentes (se jocosas ou respeitosas) e o fluxo de alimentos e objetos, pela troca ou pelo compartilhamento. Entre os Manxineru, as relações respeitosas se fazem acompanhar (pela espera) de um compartilhamento de comida e de recursos e, analogamente, as relações jocosas têm o aspecto de uma troca simétrica de brincadeiras e se fazem acompanhar por contextos de 
relações materiais também simétricas, quando qualquer doação ou empréstimo é feito sob o horizonte de uma reciprocidade esperada (Matos 2018a:54).

Entre os Warao, a partilha de alimentos cozidos é feita dentro de um casario familiar, enquanto a partilha entre casarios familiares é de alimentos crus, com uma expectativa frouxa de reciprocidade. Distanciando-se da análise em termos de conformidade com regras ou adesão a valores sociais ou virtudes, Allard é levado à fórmula recursiva que identificamos como "performance": "As pessoas alimentam você porque são seus parentes e são seus parentes porque elas o alimentam" (2010:69). E como são performances com que estamos lidando, todo ato de dar ou compartilhar tem um efeito incerto: ele corresponderá às expectativas? Quais expectativas foram atendidas e quais foram omitidas? (2010:70).

As etnografias manxineru (Matos 2018a), aweti (Vanzolini 2015) e warao (Allard 2010) sugerem uma continuidade entre palavras e coisas trocadas. No primeiro caso, vemos como os nomes e os termos de parentesco se colocam ao lado da circulação de alimentos e bens, e provocam ou compõem as relações (Matos 2018a:64). O caso warao mostra como comentários verbais sobre a fala e a ação de outros, bem como atos específicos de dar e compartilhar são avaliados moralmente, e são também avaliações de atos anteriores de outros: são sempre respostas. Se as famílias e as redes de parentesco warao são de composição instável, no final elas "emergem dos argumentos [palavras] sobre a produção e o consumo de alimentos, que são ao mesmo tempo afetivos [...] e morais [...]" (2010:66). Nos termos mais sucintos de Gow: é a "prática concreta" que faz e desfaz relações de parentesco (1991:150). Em nossa análise, o efeito de uma performance é fazer ou desfazer relações.

\section{Modalidades de causação}

Devemos ter o cuidado de distinguir entre aquilo que poderíamos chamar de "causas explícitas" e "causas implícitas" para a ação. As diferenças são de grau, mas são significativas. Em um extremo temos as relações em que as partes estão "forçando os outros a serem a causa de suas próprias ações" (Strathern 1992:180). As descrições de Viveiros de Castros (1986) da guerra tupinambá, em que guerreiros se esforçavam para se tornar o objeto da consideração vingativa de seus inimigos, é talvez o caso mais evidente. Mas pensemos igualmente no orador yanomami em um diálogo cerimonial, que pressiona seu oponente a considerá-lo um aliado, literalmente colocando essas palavras em sua boca (Kelly 2017). De maneira mais geral, apelos ao sofrimento de alguém para induzir a reação de outra pessoa, ou os movi- 
mentos intimidatórios para instilar o medo são exemplos nos quais a causa é explicitada. O ponto crucial é que se a causa termina por se tornar clara é porque há ou se assume algum grau de resistência por parte do agente.

Por outro lado, temos uma gama de situações em que as partes obrigam mais sutilmente os outros a agir, formulações que equivalem a "pedir sem pedir". As observações de Walker (2013) sobre a Urarina são prototípicas: "Em geral, a ênfase é colocada menos em 'demandar' do que em 'causar a doação'. É importante ressaltar que esse 'causar' não é coercitivo, mas repousa em induzir gentilmente o impulso benevolente e atencioso apropriado nos outros" (2013:112). Há também situações que exigem o disfarce ou a ocultação da causa. O uso de crianças ou mesmo do antropólogo em campo para pedir coisas que poderiam ser negadas é um meio indireto de disfarçar uma causa (ver Matos 2018a; Allard 2010). Outro contexto no qual a causa deve ser sistematicamente ocultada é o emprego do que poderíamos chamar de "plantas de influência" (ou pussangas, como se diz na Amazônia Ocidental): a eficácia em obter o efeito desejado (seduzir ou conquistar mais facilmente o apoio ou a simpatia dos outros) depende do ocultamento da utilização dessas plantas - qualquer tentativa de seduzir alguém é imediatamente frustrada caso o destinatário da manobra desconfie que o pretendente faz uso de tais plantas.

Quando os parentes costumam "pensar", "lembrar" ou antecipar as necessidades uns dos outros, esses outros são uma espécie de "causa inerte" da ação. Poderíamos dizer que são instâncias nas quais as pessoas são "apoios" umas para as outras (os termos são de Strathern 1988). Nesses contextos, a relação causal ou de influência que os parentes exercem sobre o agente é trazida à luz principalmente quando ocorre o fracasso em atender às expectativas.

Em sua capacidade de promover sentimentos de convívio e criar a disposição nos corresidentes para que participem de algum empreendimento coletivo, para resolver disputas internas, ou para consolidar uma posição comum diante de outras comunidades ou de representantes do Estado, o discurso de pessoas influentes, ${ }^{4}$ de homens e mulheres lideranças, de anciões etc. deve funcionar muitas vezes também como um dispositivo de dissimulação. Se a persuasão é o que substitui os comandos explícitos em muitas sociedades das terras baixas da América do Sul, é menos através de algum tipo de convencimento ou consenso do que gerando sentimentos de corresidência que pessoas influentes podem criar uma unidade a partir de um conjunto múltiplo e muitas vezes dividido de pessoas, famílias ou casarios. A resposta esperada para um "pedir sem pedir" nesses contextos é que os corresidentes atuem como se fosse por vontade própria. Pessoas influentes 
são a causa do efeito de agrupamento ao fazerem os corresidentes agirem em nome da comunidade, que então se estende para além dos vetores mais comuns e mais limitados de consideração mútua - o casario, a família, a facção etc.

O que pode diferenciar os contextos nos quais a causa é inerte daqueles em que ela é oculta ou explicitada é a falta de resistência assumida por quem é levado a agir. Os parentes precisam antecipar as necessidades uns dos outros e não deveriam precisar apelar para demonstrações explícitas de sofrimento. ${ }^{5}$ É por isso que pedir coisas diretamente aos parentes equivale a uma acusação implícita de mesquinharia (Matos 2018a:49). Mutatis mutandi, apelos ao sofrimento de alguém são frequentes em relação aos brancos (Allard 2010; Kelly 2011). Certas formas de pedir explicitamente empurram as relações de parentesco para o não parentesco, e esta é em parte a razão de sua evitação. A habilidade de pessoas influentes se assenta na capacidade de fazerem algo inverso a isto: transformar as relações que não são de parentesco em relações de parentesco, ou de corresidência - os líderes podem se dirigir metaforicamente aos membros da comunidade como seus filhos ou, em qualquer caso, com termos que impliquem corresidência convivial. Se o efeito desejado é produzir uma "comunidade" como um objeto unificado da consideração das pessoas, a fala de pessoas preeminentes deve atuar como um tipo de "causa inerte". Exigências explícitas pressupõem ou implicam a resistência presumida dos interlocutores: tais exigências lembrariam aos ouvintes as razões que os separam e que dividem a comunidade. A causa explícita presume uma determinada separação ou introduz uma separação inesperada; a causa inerte presume o contrário (i.e., a não separação) ou induz uma sobreposição ou a obviação das separações.

\section{Clastres: poder e influência}

Pode parecer fora de propósito retornar aqui aos ensaios de Clastres sobre o poder político na América do Sul, mas acreditamos que a nossa análise da ação ilumina aspectos instigantes da investigação clastriana. Ao longo das últimas décadas foram elaboradas várias críticas à antropologia política de Clastres (entre as mais conhecidas, ver Descola 1988; e Santos Granero 1993), assim como reavaliações e recuperações de diferentes faces de sua contribuição à etnologia sul-americana (por exemplo Lima \& Goldman 2001; Sztutman 2012; Vanzolini 2011; Viveiros de Castro 2011; Perrone-Moisés, Sztutman \& Cardoso 2011). Uma análise dessa literatura estaria fora do escopo deste trabalho. Gostaríamos, não obstante, de apontar 
algumas consequências que as ideias que propomos sistematizar têm sobre uma distinção mobilizada por Clastres em sua abordagem do poder nas sociedades indígenas. Trata-se da distinção entre "poder coercitivo" e "poder não coercitivo", o primeiro associado à relação de comando-obediência e o segundo à sua ausência que, por essa mesma razão, faz dele o tipo de poder pertinente ao ethos político ameríndio.

Como é notório, Clastres buscou mostrar que "alguma coisa existe na ausência" do poder coercitivo (2003:38) e, nesse movimento, ele reconfigurou toda a oposição entre uma sociedade "com" e uma sociedade "sem o Estado": o "contra o Estado" aponta para uma "diferença de outra natureza" (Lima 2011:625). Pensamos que pode ser produtivo retomar a referida distinção, desta vez prestando atenção especial em um dos polos da oposição, para propor que existe algo que escapa à dualidade coerção/não coerção: há as formas de induzir, provocar ou instigar a ação de outrem que sugerimos pensar como formas de influência.

Se os agentes estão sempre respondendo a outros tomados como causas inertes ou explícitas de suas ações, podemos dizer que seus atos são induzidos, compelidos ou até coagidos por esses outros. Seja quando a causa é inerte (quando as pessoas aparecem como "apoios" umas das outras), seja quando a causa é explícita (como é o caso quando as pessoas estão "situando as outras moralmente"), o fato é que a pessoa como causa torna-se um ponto de referência para alguém agir. Este tipo de efeito singularizador deve ser o que leva Strathern a declarar sem rodeios: "eis a coerção" (1988:272). ${ }^{6}$ Devemos aqui distinguir entre uma dinâmica da influência - que de maneira mais ou menos sutil (ou mais ou menos veemente), conforme o caso, atualiza sempre uma relação de interdependência de quem se coloca como a causa de uma ação e o agente, e que constitui assim uma "política da consideração" - e as formas da coerção nas quais um sujeito age sobre a nulidade de outros tomados como objetos, coerção que pressupõe um poder que se separa da sociedade e que se exerce violentamente segundo uma relação de comando e obediência. O antônimo do sujeito que age pelo tipo de influência que descrevemos não é um indivíduo autônomo, mas antes uma pessoa perigosamente destacada de qualquer relação. Dito de outra forma, o tipo de poder que descrevemos impõe a interdependência.

Se o agente está antecipando, "lembrando" uma causa explícita ou reagindo a ela, está sempre respondendo a um tipo de singularização: tornar-se a causa da ação de outrem é um feito, uma realização bem-sucedida. A eficácia da causa é registrada na resposta daquele que age, denotando em que medida se exerce influência sobre esse agente. O agente, por sua vez, age escolhendo levar em conta uma ou outra causa, entre outras possibili- 
dades. A causa é a sua motivação, mas é o agente que atualiza ou transforma a relação. Neste ponto ocorre outra singularização: a ação se institui como um evento, que marca também uma segunda forma de influência - o ato seletivo. Se o poder pode ser pensado como uma espécie de influência ou de incidência de uma pessoa sobre a outra, temos aqui uma dinâmica da influência com dois estágios: há a causa que compele e há o agente que seleciona. E nada está garantido: a causa e o agente fornecem de maneira respectiva a evidência da influência de um e de outro. De saída vulneráveis e incompletas em sua capacidade de agir, as pessoas devem se valer do medo, da vergonha, da compaixão, da solidariedade, da alegria e da sedução, entre outros afetos, para incidir sobre si e sobre os outros. ${ }^{7}$ Trata-se assim de uma espécie de "microfísica da influência".

Podemos, com um espírito clastriano, perguntar o que impede que esse poder microfísico que analisamos se torne uma relação de comando e obediência. Um ponto crucial nesta estrutura da ação, na qual as pessoas são objetos de consideração mútua, é que há uma alternância, e uma pessoa é tanto a causa como o agente. A articulação dessa dualidade implica tempo e perspectiva. Segundo o tempo, a esposa é a causa da caça do marido, porque ela também satisfez as suas expectativas anteriores em relação aos produtos do roçado. Em perspectiva, os atos de ontem (esposa como agente, marido como causa) transmutam-se em causas hoje (esposa como causa, marido como agente). Em outras palavras, todo ato é simultaneamente resposta e antecipação. ${ }^{8}$ Seja em relações simétricas ou assimétricas, é a alternância, ou o caráter sempre provisório de causas, atos e relações singularizadas, que inibe a perda de interdependência sobre a qual o estatuto de pessoa é predicado. Nesse mesmo sentido, essa alternância também inibe a transformação desse tipo de poder microfísico em relações mais estáveis e duradouras de comando e obediência. Alternância e transitoriedade das posições, vulnerabilidade e incompletude das pessoas: estas considerações sobre a ação e a influência vão ao encontro das formulações de Lima sobre a necessária circulação e duração da "função-eu" que instiga a ação coletiva entre os Yudja (2005:94-100).

\section{Mestres-donos}

A relação mestre-dono foi descrita recentemente como uma característica geral das sociocosmologias ameríndias (Fausto 2008). Essas descrições tomam uma "assimetria familiarizante", uma "filiação adotiva", ou ainda uma "metafiliação" como um esquema relacional chave, ou um "operador 
cosmológico", ao lado da afinidade simétrica (ver Viveiros de Castro 2002). Há pouca dúvida de que a figura do mestre-dono seja amplamente difundida entre os povos amazônicos, servindo como um esquematismo para muitas relações, incluindo aquelas entre pessoas e coisas, xamãs e seus espíritos auxiliares, chefia e coletivo, donos dos animais e esses animais, espíritos donos e os seus lugares, patrões brancos e seus trabalhadores indígenas. As terras baixas da América do Sul configuram um universo repleto de mestres-donos, no qual as relações de controle e cuidado estão combinadas, como na imagem dos donos humanos e seus animais de estimação (cf. Costa 2017).

Fausto vê no esquema relacional mestre-dono uma possibilidade de renovar as discussões sobre poder nas terras baixas da América do Sul, discussões estas que pareciam se limitar ao dilema entre a adoção de um "modelo antiestatal (obsedado negativamente pelo Estado)" ou de um "modelo de centralização teleológico (obsedado positivamente pelo Estado)". Para sair desse impasse, argumenta Fausto, deveríamos elaborar novas formas de conceituar as relações assimétricas (2008:342).

Nossa discussão não tem as relações assimétricas como objeto principal, mas a separação que analisamos entre a causa e o agente, o nosso foco nos modos pelos quais se estrutura a ação e o fato das evidências da eficácia pessoal se registrarem em outras pessoas (isto é, ação e influência se confundem) vão ao encontro das considerações de Fausto de duas formas.

Em primeiro lugar, ao colocar a questão ampla de "como as pessoas têm efeitos umas sobre as outras?" (2008:342), ele nos leva a perguntar "qual é, afinal, o impacto dos mestres?" (:343). Sua resposta é que "a potência do mestre é a capacidade de extrair uma ação do xerimbabo. Esta é a coerção, como diria Strathern" (:244). Outros autores, como Costa $(2013,2017)$ e Walker $(2012,2013)$, são levados a conclusões análogas, vinculando a agência às relações assimétricas e à figura do mestre-dono. Diríamos, no entanto, que se um mestre-dono tem a capacidade de extrair uma ação de seu xerimbabo, é porque é assim que qualquer ação acontece, em qualquer contexto. A relação mestre-xerimbabo seria uma modulação particular de uma estruturação geral da ação e não uma precondição para a agência de forma geral.

Aqui se faz necessária uma digressão. Parece-nos que os autores que recentemente se debruçaram mais especificamente sobre o tema da agência nas terras baixas da América do Sul (p.ex., Sztutman 2012, 2009; Fausto 2008; Costa 2013, 2017) têm se ocupado principalmente com a análise dos processos de constituição de "personagens" (chefes, guerreiros, xamãs) e seus modos de subjetivação. Sztutman (2012) inovou esta discussão ao associar esses processos à "personificação" do poder e à "magnificação" da 
pessoa (sensu Strathern), quando o personagem contém um coletivo e assim catalisa o surgimento de uma unidade pela obviação ou pelo eclipsamento de uma pluralidade prévia. É neste momento que se constituem um agente e seu domínio político, sempre provisório (Sztutman 2012:295). Fausto, por sua vez, associa o mestre-dono a esta pessoa magnificada, enquanto Costa descreve os donos-corpos kanamari (alimentador/a ou chefe) contendo ou "subsumindo" um ou muitos outros.

Estas abordagens da "personificação do poder" partem de uma forma ou de outra da investigação clastriana (para prosseguir com ela ou para promover-lhe reparos). Gostaríamos de toda maneira de sugerir que, quando observamos uma relação de domínio ao lado de outras instâncias, como as relações entre cônjuges ou entre "parentes reais", o que salta à vista é a necessidade de prestar maior atenção às causas que se separam do agente, à diferença entre agir e fazer agir, ao fato de que há sempre um outro que causa ou provoca a individuação da qual emerge um agente. Se, como dissemos anteriormente, as pessoas influentes devem por vezes se colocar como causa inerte de um grupo, não é menos certo que elas assim o fazem por serem forçadas, causadas a se constituir por um grupo, pois, como diria Clastres, o chefe está sempre em dívida (ver Lima \& Goldman 2001:298). Talvez seja esta uma forma de tematizar o caráter paradoxal do que fundamenta o poder de pessoas influentes: a obviação de sua causa em um grupo. E, como veremos a seguir, não podemos esquecer tampouco que há uma outra causa que não está no grupo, mas fora dele.

Precisamos perguntar também sobre a pertinência ou as limitações, em cenário amazônico, da distinção stratherniana entre "contextos coletivos" e "contextos particulares" (Strahern 1988:274-279), e sobre a aplicabilidade da dinâmica "dividual" e da alternância de socialidades que lhe corresponde, tal como ela é descrita para a Melanésia. Inicialmente, poderíamos associar os "contextos coletivos" às figuras do tipo "dono de aldeia", quando um chefe "torna equivalentes a sua ação pessoal e a de um grupo" (Lima 2005:97), ou onde ele "afunila" e "coordena" as atividades de outras pessoas (Costa 2013:482), compondo assim uma unidade a partir de uma multiplicidade prévia. Já o segundo tipo de contexto, os "contextos particulares", seriam aqueles nos quais a unidade está dada, não precisando ser instigada, nas relações conjugais e entre "parentes reais", por exemplo. Se, por um lado, estes contextos assim se distinguem, pois as relações entre os cônjuges ou entre "parentes reais" enquanto díades podem ser reconfiguradas mas não obviadas em favor de uma unidade maior, por outro lado, acreditamos ser possível sugerir uma continuidade entre as relações do tipo chefia-grupo e as relações entre cônjuges e "parentes reais", uma vez que todas elas podem 
ser tematizadas enquanto composição das relações, de sua emergência como performance, ou como decorrentes de dois momentos de singularização cuja articulação é sempre um evento.

Em segundo lugar, acreditamos ser importante uma atenção mais detida às causas da ação, pois elas também podem lançar luz sobre aquela ambiguidade, instabilidade ou indecidibilidade inerente em alguns casos da relação mestre-xerimbabo, para a qual Fausto chama a atenção: "Mas há uma ambivalência aqui, pois não se sabe exatamente quem causa a ação e quem está agindo. [...] não se sabe jamais quem adotou quem, quem controla quem: para serem potentes, xamãs e guerreiros devem assegurar a condição subjetiva e a capacidade de ação de seus xerimbabos" (2008:343).

Na relação mestre-xerimbabo há sempre uma ambivalência ou instabilidade que talvez seja baseada em uma codependência, uma mutualidade e uma alternância entre ser a causa da ação e ser um agente, um diante do outro. Exemplos significativos nesse sentido são as relações de matrimônio espiritual entre um xamã e seu espírito auxiliar, como entre os Nambikwara-Maimandê, para os quais o xamã "cria" sua esposa espiritual, mas ela também o "cria" (cf. Fausto 2008:350-351). Uma mutualidade semelhante é evidente no xamanismo yanomami, no qual os "filhos" de um xamã, seus espíritos auxiliares, fornecem a ele a sua capacidade peculiar, mas, da mesma forma, ele deve cuidá-los para que eles não o abandonem - vale a pena notar que o pó alucinógeno inalado pelos xamãs é descrito por Kopenawa como alimento para os seus espíritos auxiliares (ver Kopenawa \& Albert 2015). Gibram (2016:127) descreve a criação de filhos e de certos "animais de criação" entre os Kaingang da Terra Indígena Rio da Várzea como processos de familiarização, mas também aponta precisamente para o tipo de mutualidade entre causa e agente que queremos destacar: "isso faz de quem é 'criado' mais próximo da humanidade. E não só: ao serem a causa de uma agência que exige cuidado, alimentação e controle, os 'criados' fazem com que os que 'criam' sejam também mais humanos". Este tipo de reciprocidade de cuidados e de atenção, descritos nos termos de uma "catividade" mútua, também nos vem dos Tupimanbá de Olivença.

Os Tupinambá costumam dizer que são "cativos da terra" (e das plantas), assim como a terra (e as plantas) se torna(m) "cativa(s) deles". Do mesmo modo, as mães fazem seus filhos cativos e assim levam em si a condição de virem a se tornar cativas deles também... "ser cativo" é condição e vértice das relações e é recíproco no sentido em que não há saída, se cativa e se é cativado simultaneamente (Rocha 2014:137). 
Também quando enfocamos a relação entre a chefia e um coletivo por ela liderado, podemos observar relações de codependência e mesmo de cocriação. Rocha relata que o cacique e o grupo tupinambá "se fazem mutuamente" (2014:215). Já entre os Aweti, por exemplo,

a decisão de tornar um homem chefe não parece partir de um reconhecimento de qualidades que já possui, mas de uma tentativa de proporcionar o desenvolvimento de tais qualidades [...] "Se um homem é muito bravo, resolvemos torná-lo chefe", disseram-me - é preciso domesticá-lo, portanto, como se domestica um filhote selvagem. Este último processo é por sua vez correlato à domesticação de inimigos, já que as aves, xerimbabo preferido dos xinguanos, são inimigas dos homens no céu. Um homem feito chefe é capturado de sua própria ignorância, contudo, não para tornar-se filho, como a ave, mas para tornar-se pai, já que uma de suas principais atribuições na condição de chefe representativo será falar para seu povo todas as manhãs, referindo-se a ele como "criançada" (kaminu'aza); espera-se também que dê exemplos de empenho, ao lado de uma família trabalhadora, e demonstrações de generosidade, compartilhando sempre o que possui. [...] se, por um lado, [o chefe] atua como fabricador do grupo, na condição de representante e pai aconselhador, é, por outro lado, fabricado por ele, filho, produto de seu investimento (Vanzolini 2011:42).

E há outro aspecto da pergunta pelas causas da ação que sugere que devemos pensar também em olhar para o mestre-dono a partir de um contexto mais amplo. Allard comenta que os artefatos fabricados são de quem os fez, mas em muitos casos eles são feitos para outra pessoa, por exemplo: "é especialmente o caso das redes, que as mulheres às vezes vendem aos turistas, mas com muito mais frequência as fazem para seus parentes, seus filhos, seu marido, seus irmãos ou genros" (2010:26). Se a causa da ação é a referência que orienta o agente (o objeto de sua consideração), então a causa do vínculo entre um artesão e um objeto qualquer está fora dessa relação em si. Isto pode parecer banal no caso dos objetos manufaturados, mas se torna interessante quando analisamos outros contextos nos quais as relações mestre-dono se desenvolvem. Quem ou o que motiva o xamã a cultivar relações com seus espíritos auxiliares? Não é a cura ou a defesa de seus parentes? Os homens piro que deixam a comunidade nativa para se tornarem madeireiros nas empresas dos brancos afirmam que o fazem para repassar o dinheiro ou as mercadorias adquiridas às suas esposas (Gow 1991). Assim também é o homem warao que abre um roçado e é considerado o dono dele, mas ele o faz sempre para a sua esposa (Allard 2010:26). 
Essas observações, junto às discussões sobre o estatuto dos mestres-donos, em particular nos trabalhos de Lima (2005) e Vanzolini (2011), nos levam a um aspecto da agência que ainda não havíamos encontrado: o agente como um pivô entre duas partes, ou como imerso simultaneamente em dois tipos de relações. Voltemos a Strathern neste ponto:

Isso decorre do fato de que, como pessoa, o agente é sempre socialmente distinto da causa e, ao agir por ou devido à causa, ele também atua com referência a outras causas. A esposa que cultiva comida para o marido o faz "ela mesma" porque ela é separada dele por seus próprios laços com seus parentes natais. Assim, ela age com referência a "dois tipos de homens" - seu esposo e os seus irmãos (1988:274).

Se considerarmos o xamanismo, é o xamã que pivoteia entre duas causas - seus espíritos auxiliares e os seus parentes ou conterrâneos de aldeia; o sonhador parakanã e o matador araweté estão em posição similar; o homem piro pivoteia entre sua esposa e o seu patrão; o espírito-mestre de uma espécie animal entre os xerimbabos que ele mantém e os humanos que os caçam. Isto também ajuda a explicar a já referida ambiguidade das figuras dos mestres-donos: não se pode saber de antemão qual a causa que exercerá maior gravidade sobre aquela pessoa.

Quando Strathern diz que o agente é sempre socialmente distinto da causa, devemos lembrar que é sobre a Melanésia que ela está escrevendo: "socialmente distinto" implica que o agente e a causa têm suas origens em clãs ou grupos diferentes. Nos contextos xamânicos, assim como nos contextos econômicos da patronagem na Amazônia, as distintas origens do agente e da causa da ação - entre espíritos e humanos, no primeiro caso, e entre patrões brancos e trabalhadores indígenas, no segundo caso - são dadas. No entanto, quando tratamos do contexto de lideranças e seus corresidentes, ou de mestres dos animais e as espécies sob sua proteção, podemos ver a relação mestre-dono, em sua capacidade de conter uma pluralidade sob uma singularidade unificada (como no caso de um "dono de aldeia"), como um análogo funcional dos grupos de linhagem que assim elicitam as distintas origens sociais do agente e da causa. A referência externa - a causa externa que instiga a unificação do grupo - são conjuntos indígenas análogos, unificados por outras lideranças que também englobam coletividades em si mesmas. Esta é a "pessoa magnificada": "a forma de apresentação de uma singularidade para outros" (Fausto 2008:334).

A ideia de mestre-dono também pode se referir a donos de cerimônias, mestres de cantos, chefes e a outros tipos comuns de domínio. Entre os Kuikuro, por exemplo, também encontramos donos de caminhos, donos de 
casas dos homens, de aldeias e de praças centrais. Fausto diz que ali o dono é um mediador entre um determinado recurso e a comunidade, ele é responsável pela manutenção de um recurso e pela alimentação daqueles que trabalham por ele. Mais uma vez, a comunidade mais ampla aparece como a causa externa à relação de domínio. E um par ainda mais claro de causas distintas aparece no caso dos donos de rituais: "Ser dono representa prestígio e responsabilidade: os patronos de rituais tornam-se pessoas públicas por alimentarem a coletividade humana e os espíritos-donos das festas, que são considerados seus 'filhos'" (Fausto 2008:331).

Comentamos anteriormente que a posição de uma pessoa como agente ou como causa está sujeita a uma dinâmica de tempo e perspectiva. Talvez em alguns casos de "pessoas magnificadas" essa dinâmica se articule como uma dialética de figura e fundo. Lima afirma que a melhor forma de se entender o conceito yudja iwa seria pensá-lo como o "dono da palavra", alguém que consegue "torna[r] equivalentes a ação pessoal e a de um grupo" (2005:97). Em seguida, interditando interpretações simplistas, ela nos informa: "se não deixaria de ser verdadeiro que seu estatuto dá à sua palavra o poder de incidir sobre a conduta de pessoas de seu próprio grupo, não é por isso, contudo, que ele é retratado como o 'dono da palavra': é para outros donos da palavra que ele aparece como tal, isto é, para seus similares" (Lima 2005). O reparo "para seus similares" está longe de ser trivial, pois sugere que o estatuto de dono bem pode ter a sua causa material na incidência do chefe sobre o seu próprio grupo, mas, e talvez de maneira mais marcante, ele é motivado desde fora desse grupo.

Talvez seja a análise de Vanzolini sobre a chefia aweti (2011) que melhor exemplifique a posição do chefe como pivô entre duas causas - seu grupo e um outro chefe - articulada como uma dinâmica entre figura e fundo.

Se o grupo pode aparecer enquanto unidade, para dentro e para fora, a partir da figura do chefe, este só pode aparecer enquanto chefe a partir de sua produção pelo grupo. Não se trata aqui, note-se, de afirmar que a comunidade sempre esteve lá, enquanto o chefe precisa ser produzido, pois é apenas ao se afirmar enquanto unidade no(s) momento(s) de fabricação de seu representante (sob a forma da equipe de trabalho que constrói a casa do chefe, por exemplo) que o grupo constitui a si mesmo como sujeito, colocando o chefe na condição de objeto. No resto do tempo, sobretudo nos rituais intercomunitários nos quais a função representativa ganha destaque, a relação irá se inverter, o chefe tornando-se sujeito de um grupo que ele congrega ao falar em seu nome (2011:42-43).

O tempo e o contexto das relações intra ou intercomunitárias parecem colocar ora o grupo local como causa-figura e um outro chefe análogo como 
causa-fundo (na esfera intracomunitária), ora inversamente, um outro chefe como causa-figura e o grupo local como causa-fundo (na esfera intercomunitária). Uma "variação yudjá", por assim dizer, é sugerida por Lima em termos de relações de simetria e assimetria: "esta é a configuração do socius que os Yudjá constituem como seu: grupos constituídos internamente por uma assimetria, interligados por uma relação de simetria que, aberta ao evento, pode apresentar estados alternados de assimetria" (2005:100). ${ }^{9}$

\section{Torções}

Luiz Costa $(2013,2017)$ faz uma exposição detalhada sobre como os Kanamari pensam a relação mestre-dono, infletida pela "alimentação", ayuh-man. A alimentação é o dispositivo actancial através do qual se criam as relações de dependência-cuidado, que vão consolidar alguém como o -warah (ou dono-corpo) de outrem. Uma vez que é apenas depois de ter sido nutrido e cuidado por alguém que se pode fazer parte de uma comunidade qualquer, ter um "dono-corpo" é também a condição necessária para habitar o espaço moral da humanidade (2017:70). Costa explicita o que seria uma "teoria kanamari da ação".

o referente do termo -warah (em uma relação ou contexto dados) tem a capacidade de agir com e por aqueles que ele ou ela contém, ao alinhar as suas atividades na dele próprio. Para os Kanamari, a agência não é imanente aos indivíduos, mas é sempre produto de uma objetificação - uma canalização ou coordenação - das atividades de outros para um fim coletivo (2017:72).

Assim, para os Kanamari, a agência é função de um dos termos da relação, o dono-corpo, cuja posição foi construída através das relações assimétricas tematizadas como "alimentação". A agência reside na pessoa singular do dono-corpo (2017:73). Não obstante, a relação de dono-corpo é constituída pelo dispositivo da alimentação (ayuh-man), glosado por Costa como uma espécie de "causar a necessidade" na pessoa alimentada, o que não se resume a uma transferência de comida, ou à mera satisfação de uma necessidade passageira. Nesse sentido, "alimentar não é um ato que cancela uma necessidade previamente existente, mas um ato que instila ou perpetua a necessidade" (2017:26). A relação de dono-corpo só é estabelecida na medida em que alguém, por atos assimétricos de alimentação, cria em outra pessoa (criança, xerimbabo ou espírito auxiliar) uma necessidade pelo dono-corpo.

Novamente, vemos um tipo de estrutura actancial recursiva mais geral, na qual o que importa é causar no outro disposições que o farão reiterar a capacidade de agir daquele que assume a posição de domínio. E, devemos 
observar, sem o desejo ou a necessidade da parte sob domínio, tampouco há o dono-corpo. Deste ponto de vista, é possível reconhecer naquele que é contido pelo dono-corpo a capacidade agentiva de fazer com que o seu -warah o alimente, de se colocar como a causa dos cuidados a ele dispensados. Trata-se de fato de uma questão de perspectiva: se a relação de maestria é muito comumente metaforizada pelas imagens de continente e conteúdo, é mister reconhecer o limite onde tais imagens evocam uma garrafa de Klein: o limiar em que o que contém é também contido pela necessidade daquele que ele alimenta ou nutre.

Com efeito, quando nos voltamos para o modo como os Paumari (também do sudoeste da Amazônia, no médio rio Purus) conceituam suas relações com os patrões brancos, cruzamos aquele limiar. Pamoari, a autodesignação usada pelos Paumari, indica a capacidade de ter um ponto de vista, ou a humanidade enquanto condição no seio de uma coletividade, mas pode significar também o cliente ou aviado, isto é, alguém que recebe mercadoria de um patrão. Trata-se de uma posição mais geral, que tem em uma de suas transformações a ideia de hohai abono, um empregado de um patrão, alguém que está sob as ordens ou a serviço de outrem (Bonilla 2005, 2016). Bonilla mostra como os Paumari, quando diante de estrangeiros perigosos ou reputados como mais poderosos, oscilam estrategicamente entre as duas posições: a sujeição é aqui um dispositivo para transformar inimigos terríveis em "pais adotivos" (ou padrinhos), ou ainda em sogros potenciais, o que exclui a violência desmedida da predação direta.

É essa sujeição voluntária por parte dos Paumari que permite a contracaptura de estrangeiros vistos como potencialmente perigosos e vorazes. Em outras palavras, colocando-se na posição de presa-cliente, os Paumari forçam o interlocutor a adotar a posição de familiarizador correspondente, evitando assim a ameaça iminente de serem tomados como presas e de serem devorados, ao menos temporariamente, ao mesmo tempo em que criam a possibilidade de uma sujeição e idealmente de um parasitismo, como forma de acesso ilimitado e unívoco aos bens desejados. [...] a arma predatória dos Paumari é, sem dúvida, sua capacidade de serem submetidos, forçando o interlocutor a se colocar na posição dominante e a ter pena deles e adotá-los como se fossem de fato "patinhos sem mãe". Predadores potenciais são deslocados de uma posição de dominação exclusiva para uma posição mais paternalista, mais dependente daqueles que se submeteram, se comprometendo a cuidar deles (Bonilla 2016:124-125).

Como notamos anteriormente, na etnografia kanamari a participação do elemento "passivo" da relação (a pessoa que é alimentada) na constituição do dono-corpo parece comparativamente muito reduzida, para não dizer 
nula. Costa, no entanto, sugere que são "os filhos [...] que consolidam o casal enquanto unidade produtiva e estável, garantindo o sucesso das uniões matrimoniais" (2013:484). Assim, em certo sentido, são os filhos que permitem que os pais se constituam enquanto donos-corpos. Bonilla, por sua vez, mostra a partir da etnografia paumari uma perspectiva inversa e complementar, a saber: as pessoas paumari se posicionam como a causa que compele o comportamento protetor de seus patrões que, por sua vez, são posicionados como agentes. Não deixa de chamar a atenção que a transformação operada pelos Paumari, de "patrões predadores" em "patrões protetores", seja também tematizada em um mito kanamari, no qual o jaguar é transformado de um dono-corpo predador em uma multiplicidade de donos-corpos alimentadores (Costa 2013:493). O mito é kanamari, mas sua "lógica" é também paumari. Esse contraste nos leva a pensar que, mesmo nos casos nos quais as relações assimétricas são culturalmente ou analiticamente predominantes, a mutualidade está presente entre a causa e o agente. ${ }^{10}$

Devemos observar que nestes contextos a alternância também não deixa de estar presente. Ela se encontra nas dinâmicas entre causas-figura e causas-fundo às quais nos referimos acima; ou ela se desenvolve ao longo do ciclo de vida, quando alguém que era dependente se torna alimentador; ou ainda ela se evidencia nas posições simultaneamente ocupadas por alguém que é a causa para a ação de uma pessoa ou grupo, mas é ao mesmo tempo o agente diante de outras pessoas ou grupo (ver também Costa 2013).

\section{Conclusão}

Sabemos que esse nosso esboço de uma "política da consideração" está incompleto. Para encerrar este nosso primeiro esforço, gostaríamos de destacar algumas ideias apresentadas, sobretudo apontando as limitações de nossa abordagem. Se associamos nossa abordagem da ação e da influência a uma "política da consideração", é porque quisemos indicar algo como uma dívida em relação às etnografias que sugeriram uma "política dos afetos". A articulação que faz Surrallés (2009) entre os afetos e a ação pelos Candoshi; as observações de Vanzolini (2015) sobre o ciúme/inveja como motor do feitiço entre os Aweti; a análise de Ramo y Affonso (2014) das interferências de socialidades extra-humanas nos afetos entre os Guarani; ou de Beatriz Matos (2018) sobre a captura de atributos para a constituição das pessoas e de suas relações entre os Matses, por exemplo, oferecem elementos imprescindíveis para elaborações de maior alcance. Enfim, falta-nos uma reflexão mais aprofundada sobre as articulações entre influência e afetos, e entre os motores e os alvos da ação. ${ }^{11}$ 
Não pretendemos sugerir para este nosso esforço qualquer originalidade substantiva. Buscamos apenas sistematizar ideias que já se encontram em diversas etnografias, oferecendo um desenho suficiente e com certo potencial de generalização para os povos ameríndios. A separação entre a causa e o agente, as diferentes modalidades da causação (a causa inerte, a causa oculta, a causa explícita), a dinâmica de mutualidade e alternância e o caráter performativo da influência que os articulam constituem uma "política da consideração" no triplo sentido que o termo "consideração" evoca (especialmente, como comentamos na Introdução, à luz de seu análogo em inglês, regard) - "cuidar", "olhar" ou "prestar atenção", e "pensar" em algo ou em alguém de uma forma particular, forma esta que pode ser definida pelo jogo entre ser (ou não) objeto de consideração de outrem, e atuar (ou não) levando outras pessoas em consideração. Deve-se observar que um aspeto importante desta política envolve aquelas modalidades de causação, que distinguem uma causa explícita ou oculta, de um lado - em que se assume a resistência do potencial agente ou em que se introduz uma diferença substantiva ou um hiato entre as pessoas (entre parentes afins e consanguíneos, por exemplo), e a causa inerte na qual as pessoas são "apoios" para os atos de outros - e aqui não estão supostas resistências ou atos de obviação que separam as pessoas (ao se constituir um grupo como objeto de consideração coletiva, por exemplo). Os mundos amazônicos parecem permeados de pessoas que se colocam o tempo todo como causas explícitas, ocultas ou inertes das ações de outrem. Talvez por isso "nada é sem razão", como não cansa de nos avisar Davi Kopenawa (Kopenawa \& Albert 2015).

Nosso esboço inevitavelmente se ramificou em direção às discussões acerca da ação e do poder político entre os povos ameríndios. Isto justifica a nossa abordagem um tanto "lateral" (ou mesmo enviesada) dos debates acerca do poder e das relações de maestria-domínio. Por um lado, a performatividade e a dinâmica da influência inerentes à estruturação da ação parecem oferecer elementos para uma descrição etnograficamente sensível e, em certo sentido, alternativa à oposição clastriana entre um "poder coercitivo" e um "poder não coercitivo".

Por outro lado, somos tentados a perguntar se esta "política da consideração" não teria uma aplicação mais ampla do que o operador cosmológico mestre-xerimbabo quando se trata de analisar as relações entre as noções de agência, de causalidade e de pessoa. A questão parece especialmente pertinente quando percebermos que tal política da consideração parece vigorar em contextos que não são marcados por relações de domínio (como as relações entre casais piro ou manxineru), assim como em povos entre os quais este operador é comparativamente pouco desenvolvido (como parece ser o 
caso dos Yanomami). Poderíamos sugerir que é esta política da consideração que assume contextualmente as feições de uma relação dono-xerimbabo, naquelas situações nas quais o operador mestre-dono é significativo.

Ver o agente como pivô entre duas causas também nos levou a observar, como já fizeram Lima (2005) e Vanzolini (2011), que há uma necessária abertura da relação de maestria-domínio a um terceiro elemento, exterior àquela relação. Este terceiro elemento é aquele que geralmente permite uma dinâmica de alternância e de deslocamentos contextuais entre as causas e os agentes, o que nossa descrição em termos de causa-figura e de causa-fundo apenas indica. Não podemos deixar de ver neste jogo do agente entre duas causas ressonâncias com a dinâmica do dualismo triádico identificado por Lévi-Strauss nas organizações sociais e nas mitologias ameríndias (ver Lévi-Strauss 1991; e sobretudo Lima 2008). Aqui existem conexões que deveriam ser mais bem desenvolvidas entre o tema da agência e o perspectivismo ameríndio, considerando que "justo uma posição do meio se acha no coração do perspectivismo - um entre-dois" (Lima 2011:622).

Por não ser objeto direto de nossa análise, não nos engajamos com maior profundidade no tema da articulação entre relações simétricas e assimétricas, que o contraste entre alguns trabalhos acima mencionados justificaria plenamente. Devemos deixar claro, no entanto, que procuramos apontar o mais explicitamente possível para uma dinâmica de interdependência e para a alternância entre ser a causa e ser o agente nas ações, que nos parece inerente aos dois tipos de relações.

Por fim, chama a nossa atenção o fato de que os nossos interlocutores indígenas parecem estar mais interessados em individuar as causas das ações do que em simplesmente ocupar a posição de protagonistas ou agentes incontroversos. Em certo sentido, muitas vezes a modalidade de agência mais adequada ou eficaz é antes um "fazer fazer".

O que nossa discussão parece indicar é que a ação ameríndia não pode ser facilmente compreendida nos termos das dualidades "sujeito/objeto", "atividade/passividade", "espontaneidade/receptividade" etc. A ação é distribuída pragmaticamente entre as pessoas, não apenas em sua análise, mas principalmente nas tentativas dos próprios atores sociais de amplificar, aumentar a eficácia, justificar ou anular suas próprias ações e as de outrem. Isto implica um tipo arriscado de performance, isto é, significa que a eficácia de uma ação, ou a falta dela, está sempre sendo atestada ou aferida, e está sempre sob disputa.

Em um sentido mais geral, as ideias que procuramos sistematizar podem lançar luz sobre as transformações a que estão sujeitas as nossas ideias de liberdade, de autodeterminação ou de autonomia quando em solo 
amazônico. Nesse sentido, o tratamento dado por Vinciane Despret (2013) ao conceito de "agenciamento" à luz dos estudos de etologia sobre a agência interespecífica de plantas e vespas nos parece relevante. Um agenciamento, nos mostra a autora, é uma relação através da qual seres tornam outros seres capazes, de maneira que não é sempre claro quem age e quem é levado a agir: o que constitui um agente ou um paciente é distribuído e redistribuído constantemente. Despret conclui que não há agência que não seja uma interagência, conclusão que também podemos tomar para o nosso estudo: "ser um agente exige depender de muitos outros seres, ser autônomo exige ser pluri-heterônomo" (2013:44).

Recebido em: 03 de abril de 2019

Aceito em: 16 de junho de 2019

José Antonio Kelly, doutor em Antropologia Social pela Universidade de Cambridge, é professor no Programa de Pós-graduação em Antropologia Social da Universidade Federal de Santa Catarina.

ORCID https://orcid.org/0000-0002-2770-7538

E-mail: kamiyekeya@gmail.com

Marcos de Almeida Matos, doutor em Antropologia Social pela Universidade Federal de Santa Catarina, é professor na Universidade Federal do Acre.

ORCID https://orcid.org/0000-0003-0546-9345

E-mail: tapecuim@gmail.com 


\section{Notas}

* Uma versão parcial deste artigo foi apresentada no seminário Configurations socio-spatiales, enjeux politiques et débats ontologiques en Amazonie, organizado por Olivier Allard e Alexandre Surrallés em 14 de fevereiro de 2019, em Paris, e se beneficiou da discussão realizada pelos participantes. Agradecemos a Beatriz Matos e Marcela Coelho de Souza pela leitura de uma primeira versão do texto, ambas fizeram críticas e comentários fundamentais para a sua melhoria. Agradecemos também a Renato Sztutman e Eduardo Viveiros de Castro pela leitura e por suas sugestões cuidadosas de uma segunda versão. Por fim, agradecemos às/aos três pareceristas anônimas/os que também nos ofereceram uma crítica detalhada e generosa.

1 A tradução desta passagem é de nossa autoria, como a das demais passagens de textos em língua estrangeira citadas neste artigo.

2 Ainda nesse mesmo contexto de iniciação xamânica observamos que tão importante quanto ser visto pelos xapiri, conquistar a sua atenção e evitar perdê-la, é aprender a ouvi-los e a compreendê-los, como também saber responder aos seus cantos. A beleza e a verdade dos próprios cantos, como a capacidade de responder aos cantos de outrem, aparece sempre como um requisito necessário ao conhecimento xamânico. Pode-se assim dizer que em diversos contextos ouvir e responder são tão ou mais importantes que ver ou ser visto.

3 Allard (2010:108), seguindo Bloch (1971), também insiste em como os termos de parentesco são julgamentos do comportamento das pessoas, em vez de rótulos para elas, e que, como tais, funcionam como ferramentas transformadoras nas relações.

4 Através do termo "pessoas influentes" nos referimos ao amplo conjunto de personagens que possuem ou que mobilizam os atributos atribuídos por Clastres à chefia indígena. Pensamos que este termo é mais pertinente à nossa análise geral e é aberto o suficiente para incluir os homens, as mulheres e os casais que de um modo ou de outro desempenham a função de constituir coletivos extrafamiliares. Assim, a expressão pretende abarcar, por exemplo, os "grandes homens" yanomami; o wutsrukate manxineru; os chefes xinguanos; "troncos velhos" homens e mulheres e caciques kaingang (ver Gibram 2016); caciques homens e mulheres tupinambá (ver Rocha 2014); "cacicas" mbya-guarani (ver Rebelo 2015); casais "levantadores de parentelas" kaiowa e guarani (Pereira 2016; Cariaga 2019) etc.

5 Assim, nas aldeias manxineru, pudemos elicitar com facilidade as formas de se pedir caiçuma a alguém, mas as perguntas sobre como se pode pedir comida obrigavam os interlocutores a contrariar suas convenções linguísticas: de fato, ninguém costuma pedir comida nas aldeias.

6 Vale a pena ler a formulação completa de Strathern: “Um agente é aquele que age com o outro em mente, e esse outro pode de fato coagir o agente a agir assim. Uma mulher Hagen é obrigada a colher seus tubérculos para o marido. Mas seria uma má interpretação ler isso como se atestasse os poderes superiores do marido, 
uma subjetividade engrandecida sobrepujando à da esposa. Do ponto de vista da mercadoria, é verdade que um sujeito age sobre o outro como seu objeto. Aqui, sugiro, na relação correspondente, um sujeito age com outro sujeito em mente. [...] O objeto ou o resultado é o relacionamento entre as partes, o efeito de sua interação. Mas os dois sujeitos não são isomórficos. Se a esposa é um agente, a pessoa que age, então o marido, neste caso, é a causa de sua ação, embora não seja ele mesmo ativo. É simplesmente em referência a ele que a esposa age. Eis a coerção" (Strathern 1988:272).

7 Em uma direção semelhante Menget, por exemplo, define o poder como uma "capacidade de fazer fazer" (1993:70), exemplificando essa capacidade como a habilidade de certos chefes xinguanos em manipular rumores, palavras e alusões, no sentido de fortalecer, confirmar ou mesmo estabelecer seus poderes (1993:71).

8 "Pessoas e agentes ocupam posições definidas por diferentes pontos de vista. A mesma figura é tanto um objeto de consideração dos outros (uma pessoa) quanto alguém que age como ele ou ela em nome desses outros (um agente)" (Strathern 1988:273-4).

9 Lembremo-nos também das observações de Sztutman sobre os diferentes aspectos dos processos de magnificação entre os antigos Tupi. Ele distingue entre a ação política, que compõe um coletivo, e a representação política, que implica outros coletivos: a primeira estaria ligada à "liderança" e se trataria de um "fenômeno central", a segunda estaria ligada à "chefia", sendo "deliberadamente precária" $(2005,2009: 32-33)$.

10 Parece ser isso que Munn quer sublinhar ao falar da definição do valor de conchas e homens na ilha de Gawa: estes últimos "parecem ser os agentes ao definirem o valor das conchas, mas, de fato, sem conchas os homens não podem definir o seu próprio valor: a esse respeito, conchas e homens são reciprocamente os agentes da definição de valor uns dos outros" (citado por Strathern 1988:174).

11 Uma integração nesse sentido é apontada em outros termos por Viveiros de Castro: "talvez o problema da magia seja o problema do parentesco; talvez sejam ambos soluções complementares para o mesmo problema: o da intencionalidade e da influência, da misteriosa eficácia da relacionalidade" (2009:146). Uma síntese comparativa de dispositivos de influência e de afetação, tais como os sonhos, os cantos xamânicos e as plantas e outras substâncias mágicas, seria um caminho possível para esta empreitada. 


\section{Referências bibliográficas}

ALÈS, Catherine. 2000. "Anger as a marker of love: The ethic of conviviality among the Yanomami". In: J. Overing \& A. Passes (eds.), The anthropology of love and anger: the aesthetics of conviviality in native Amazonia. London: Routledge. pp. 133-151.

ALLARD, Olivier. 2010. Morality and Emotion in the Dynamics of an Amerindian Society (Warao, Orinoco Delta, Venezuela). PhD Dissertation, University of Cambridge.

BLOCH, Maurice. 1971. "The moral and tactical meaning of kinship terms". Man, 6:79-87.

BONILLA, Oiara. 2005. "O bom patrão e o inimigo voraz: Predação e comércio na cosmologia paumari". Mana 11 (1):41-66.

. 2016. "Parasitism and subjection: Modes of Paumari predation". In: Marc Brightman; Carlos Fausto \& Vanessa Grotti (eds.), Ownership and Nurture: Studies in Native Amazonian Property Relations. Oxford and New York: Berghahn. pp. 110-132.

CARIAGA, Diógenes. 2019. Relações e diferenças: a ação política kaiowá e suas partes. Tese de Doutorado, Universidade Federal de Santa Catarina.

CLASTRES, Pierre. 2003 [1974]. A sociedade contra o Estado: pesquisas em antropologia política. São Paulo: Cosac \& Naify.

COSTA Luiz. 2013. "Alimentação e comensalidade entre os Kanamari da Amazônia Ocidental". Mana, 19 (3):473-504.

. 2017. The owners of kinship: assymetrical relations in indigenous Amazonia. Chicago: HAU books.

EWART, Elizabeth. 2008. "Seeing, hearing and speaking: morality and sense among the Panará in central Brazil". Ethnos, 73:505-522.
DESCOLA, Philippe. 1988. "La chefferie amérindienne dans l'anthropologie politique". Revue Française de Science Politique, 38:818-827.

DESPRET, Vinciane. 2013. "From secret agents to interagency". History and Theory, 52:29-44.

DE VIENNE, Emmanuel. 2012. "Make yourself uncomfortable. Joking relationships as predictable uncertainty among the Trumai of Central Brazil". HAU: Journal of Ethnographic Theory, 2 (2):163-87.

FAUSTO, Carlos. 2008. "Donos demais: maestria e domínio na Amazônia". Mana, 14 (2):329-366.

GIBRAM, Paola. 2016. Penhkár: política, parentesco e outras histórias kaingang. Curitiba: Appris; Florianópolis: Instituto Nacional de Pesquisa Brasil Plural.

GOW, Peter. 1991. Of mixed blood: kinship and history in Peruvian Amazon. Oxford: Oxford University Press. . 2000. "Helpless: The Affective Preconditions of Piro Social Life". In: J. Overing \& A. Passes (eds.), The anthropology of love and anger: the aesthetics of conviviality in native Amazonia. London: Routledge. pp. 46-63.

HUGH-JONES， Stephen. 1992 . "Yesterday's luxuries, tomorrow's necessities: Business and barter in Northwest Amazonia". In: C. Humphrey \& S. Hugh-Jones (orgs.), Barter, Exchange and Value: an anthropological approach. Cambridge: Cambridge University Press. pp. 42-74.

KELLY, José Antonio. 2011. State healthcare and Yanomami transformations: a symmetrical ethnography. Tucson: University of Arizona Press. 
2017. "On Yanomami ceremonial dialogues: a political aesthetic of metaphorical agency". Journal de la Société des Américanists, 103 (1):179-214

KOPENAWA, Davi \& ALBERT, Bruce. 2015. A Queda do Céu: palavras de um xamã yanomami. Trad. Beatriz Perrone-Moisés. São Paulo: Cia das Letras.

LÉVI-STRAUSS, Claude. 1991. Histoire de lynx. Paris: Plon.

LIMA, Tânia Stolze. 2005. Um peixe olhou para mim: o povo Yudjá e a perspectiva. São Paulo: Unesp.

. 2008. "Uma história do dois, do uno e do terceiro". In: Ruben Caixeta de Quieroz \& Renarde Freire Nobre (orgs.), Lévi-Strauss: leituras brasileiras. Belo Horizonte: Editora UFMG. . 2011. "Por uma cartografia do poder e da diferença nas cosmopolíticas ameríndias". Revista de Antropologia, 54 (2):601-646.

LIMA, Tânia Stolze \& GOLDMAN, Márcio. 2001. "Pierre Clastres, etnólogo da América". Sexta-Feira, 6:291-309.

MATOS, Marcos de Almeida. 2018a. Organização e história dos Manxineru do alto rio Iaco. Tese de Doutorado, Universidade Federal de Santa Catarina.

2018b. "Parentesco por brincadeira no alto rio Iaco". Anuário Antropológico, v. 43, n. 2:207-228.

MATOS, Beatriz. 2018. "Povo onça, povo larva: animais e plantas na constituição da pessoa, diferenciação de gênero e parentesco matses". Revista de Antropologia, 61 (3):109-129.

MENGET, Patrick. 1993. "Les Frontières de la chefferie Remarques sur le système politique du haut Xingu (Brésil)". L'Homme, 33, 126-128:59-76.

PEREIRA, Levi. 2016. "Levantadores de parentela kaiowá e guarani em Mato Grosso do Sul: agência e atualização de saberes na produção de socialidade". In: N. Heusi Silveira; C. Roch de Melo \& S. Cavalheiro de Jesus (orgs.), Diálogos com os Guarani: articulando compreensões antropológicas e indígenas. Florianópolis: Editora da UFSC.

PERRONE-MOISÉS, Beatriz; SZTUTMAN, Renato \& CARDOSO, Sergio. 2011. "Dossiê Pensar com Pierre Clastres". Revista de Antropologia, 54 (2)

REBELO, Francine. 2015. Kunhangue Mba'e Kua: as trajetórias das mulheres cacicas Guarani Mbya de Santa Catarina. Dissertação de Mestrado, Universidade Federal de Santa Catarina.

ROCHA, Cinthia. 2014. "Bora a vê quem pode mais": Uma etnografia sobre o fazer política entre os Tupinambá de Olivença (Ilhéus, Bahia). Tese de Doutorado, Universidade Federal de Santa Catarina.

SANTOS-GRANERO, Fernando. 1993. "From prisoner of the group to darling of the gods: an approach to the issue of power in Lowland South America". L'Homme, 126-128:213-230.

STRATHERN, Marilyn. 1988. The gender of the gift: Problems with women and problems with society in Melanesia. Berkeley and Los Angeles: University of California Press.

. 1992. "Qualified Value: The Perspective of Gift Exchange". In: C. Humphrey \& S. Hugh-Jones (orgs.), Barter, Exchange and Value: an anthropological approach. Cambridge: Cambridge University Press. pp. 169-191.

SURRALLÉS, Alexandre. 2009 [2003]. En el corazón del sentido: percepción, afectividad, acción en los candoshi, Alta Amazonía. Lima: Institut Français des Études Andines. 
SZTUTMAN, Renato. 2009. “De caraíbas a morubixabas: a ação política ameríndia e seus personagens". Revista de Antropologia dos Alunos do PPGAS-UFSCAR, 1 (1):16-45.

. 2012. O profeta e o principal: a ação política ameríndia e seus personagens. São Paulo: Edusp.

VANZOLINI, Marina. 2011. "Eleições na aldeia ou o Alto Xingu contra o Estado?". Anuário Antropológico, v. 36, n. 1:31-54.

. 2015. A flecha do ciúme: o parentesco e seu avesso segundo os Aweti do Alto Xingu. São Paulo: Editora Terceiro Nome.

VIVEIROS DE CASTRO, Eduardo. 1986. Araewté: os deuses canibais. Rio de Janeiro: Anpocs/ Jorge Zahar Ed. . 2002. "O problema da afinidade na Amazônia". In: A Inconstância da Alma Selvagem e outros ensaios de antropologia. São Paulo: Cosac e Naify. pp. 86-180.
2009. "The Gift and the Given: three nano-essays on kinship and magic". In: The Relative Native: Essays on Indigenous Conceptual Worlds. Hau Books: Chicago. . 2011. "O intempestivo, ainda". In: Pierre Clastres, Arqueologia da Violência: pesquisas de antropologia política. Trad. Paulo Neves. São Paulo: Cosac e Naify. pp. 297-361.

WAGNER, Roy. 1972. Habu: the innovation of meaning in Daribi religion. Chicago: The University of Chicago Press.

. 1981. The invention of culture. Chicago: University of Chicago Press. WALKER, Harry. 2012. "Demonic Trade: debt, materiality and agency in Amazonia". Journal of the Royal Anthropological Institute, 18:140-159. . 2013. Under a Watchful Eye: self, power, and intimacy in Amazonia. Berkeley: University of California Press. 


\section{POLÍTICA DA CONSIDERAÇÃO: AÇÃO E INFLUÊNCIA NAS TERRAS BAIXAS DA AMÉRICA DO SUL}

\begin{abstract}
Resumo
Este artigo procura esboçar alguns elementos para a caracterização do que sugerimos chamar de uma "política da consideração" pertinente às formas de ação e organização dos coletivos indígenas nas terras baixas da América do Sul. Trata-se de analisar a relação entre duas ideias de inspiração stratherniana, mas muito presentes nas etnografias produzidas na região: a) toda ação significativa poderia ser explicada, compreendida ou justificada como envolvendo a separação entre uma pessoa que age e uma outra pessoa tomada como a causa da ação; e b) ser reconhecido como pessoa, ou ocupar o lugar de um agente moral, implica estar sob a consideração de uma outra pessoa. A partir destas duas ideias, procuramos ainda revisitar alguns temas já clássicos para a literatura etnológica sobre os povos amazônicos, a saber: a relação entre o poder e a coerção e o tema dos mestres-donos.
\end{abstract}

Palavras-chave: Agência, Influência, Povos indígenas, Poder.
POLÍTICA DE LA CONSIDERACIÓN:

ACCIÓN E INFLUENCIA EN LAS

TIERRAS BAJ AS DE AMÉRICA

DEL SUR

\section{Resumen}

Este artículo busca esbozar algunos elementos para caracterizar lo que sugerimos llamar una "política de la consideración" pertinente a las formas de acción y organización de los colectivos indígenas en las tierras bajas de América del Sur. Se trata de analizar la relación entre dos ideas de inspiración stratherniana pero muy presentes en las etnografías producidas en la región: a) toda acción significativa podría ser explicada, comprendida o justificada como envolviendo la separación entre una persona que actúa, y otra persona tomada como la causa de la acción; y b) ser reconocido como persona, $u$ ocupar el lugar de un agente moral, implica estar bajo la consideración de otra persona. A partir de esas dos ideas, revisamos algunos temas ya clásicos para la literatura etnológica sobre los pueblos amazónicos, a saber: la relación entre el poder y la coerción y el tema de los maestros-dueños.

Palabras clave: Agencia, Influencia, Pueblos indígenas, Poder. 
POLITICS OF REGARD: ACTION AND INFLUENCE IN LOWLAND

SOUTH AMERICA

\begin{abstract}
This article sketches some elements of what we suggest to call a "politics of regard" pertinent to the forms of action and organization of indigenous collectives in the lowlands of South America. The purpose is to analyze the relation between two Strathernian ideas with applicability in the region: a) any
\end{abstract}

meaningful action could be explained, understood or justified as involving the separation between a person who acts and another person taken as the cause of action; and b) being recognized as a person, or occupying the place of a moral agent, implies being under the regard of another person. Considering these two ideas, we also revisit some classic themes of the ethnological literature, namely: the relation between power and coercion, and the theme of the masters-owners.

Key words: Agency, Influence, Indigenous peoples, Power. 